\title{
Development of cassava periclinal chimera may boost production
}

\author{
N. Bomfim ${ }^{1}$ and N.M.A. Nassar ${ }^{2}$ \\ ${ }^{1}$ Programa de Pós-Graduação em Botânica, Universidade de Brasília, Brasília, \\ DF, Brasil \\ ${ }^{2}$ Departamento de Genética e Morfologia da Universidade de Brasília, \\ Brasília, DF, Brasil \\ Corresponding author: N.M.A. Nassar \\ E-mail:nagibnassar@geneconserve.pro.br
}

Genet. Mol. Res. 13 (1): 819-830 (2014)

Received December 5, 2013

Accepted January 28, 2014

Published February 10, 2014

DOI http://dx.doi.org/10.4238/2014.February.10.1

\begin{abstract}
Plant periclinal chimeras are genotypic mosaics arranged concentrically. Trials to produce them to combine different species have been done, but pratical results have not been achieved. We report for the second time the development of a very productive interspecific periclinal chimera in cassava. It has very large edible roots up to 14 $\mathrm{kg}$ per plant at one year old compared to 2-3 $\mathrm{kg}$ in common varieties. The epidermal tissue formed was from Manihot esculenta cultivar UnB 032, and the subepidermal and internal tissue from the wild species, Manihot fortalezensis. We determined the origin of tissues by meiotic and mitotic chromosome counts, plant anatomy and morphology. Epidermal features displayed useful traits to deduce tissue origin: cell shape and size, trichome density and stomatal length. Chimera roots had a wholly tuberous and edible constitution with smaller starch granule size and similar distribution compared to cassava. Root size enlargement might have been due to an epigenetic effect. These results suggest a new line of improved crop based on the development of interspecific chimeras composed of different combinations of wild and cultivated species. It promises boosting cassava production through
\end{abstract}


exceptional root enlargement.

Key words: Wild Manihot; Manihot fortalezensis; Starch quality; Stem apical meristem; Root size; Interspecies epigenetic interaction

\section{INTRODUCTION}

Cassava is the principal food for more than 800 million people in the tropics and subtropics (FAO, 2013). Improvement programs have concentrated on simple clonal selection and inter-cultivar hybridization (Ceballos et al., 2004; Nassar and Ortiz, 2009). Interspecific hybridization to transfer characters is difficult due to species barriers and the need to break them (Nassar et al., 1996; Rieseberg and Carney, 1998; Ulukan, 2009). Furthermore, the introduction of undesirable characters from the wild form is another drawback, which may need a number of generations and decades to get rid of this undesirable linkage-drag. (Rieseberg and Carney, 1998; Ulukan, 2009). Polyploidy has little to offer genetic enhancement because new traits were not brought by this technique (Sreekumari et al., 1999; Aversano et al., 2013). There have been suggestions to produce chimeras to combine useful characters from wild and cultivated forms such as resistance to insects found in epidermal tissue (e.g., host plant resistance to insects found in epidermal tissue), but practical results are yet to be achieved (Goffreda et al., 1990; Marcotrigiano, 1997b; Lindsay et al., 1995; Nassar and Ortiz, 2010).

Sporadic interspecific chimeras have been documented by some authors (Stewart et al., 1972; Burge et al., 2002; Zhou et al., 2002; Chen et al., 2006; Zhang et al., 2007). They arose from adventitious shoot formed on a graft union of a scion and rootstock, on field or tissue culture conditions, for different purposes, but not for formation of advantageous varieties, under plant breeding view, and with no significative economic value (Marcotrigiano and Gouin, 1984; Goffreda et al., 1990; Kaddoura and Mantell, 1991; Marcotrigiano, 1997b; Burge et al., 2002; Chen et al., 2006).

There are sporadic reports of interspecific chimeras that had arisen from an adventitious shoot formed on a graft union of a scion and rootstock (Stewart et al., 1972; Burge et al., 2002; Zhou et al., 2002, Chen et al., 2006; Zhang et al., 2007). A few chimeras have also been produced by tissue culture, but they have no economic value (Marcotrigiano and Gouin, 1984; Kaddoura and Mantell, 1991; Chen et al., 2006).

In our earlier study, wereported the first periclinal chimera in cassava between Manihot fortalezensis and cassava cultivar UnB 201, which was highly productive (Nassar and Bomfim, 2012, 2013). In the present paper, we report a second interspecific periclinal chimera involving the Manihot species M. fortalezensis and another cultivated Manihot esculenta cultivar UnB 032, which also differ in chromosome number and ploidy level. We used the UnB 032 clone, which is known for its good food quality and moderate productivity, but it is susceptible to borers and vulnerable to drought, and the wild $M$. fortalezensis, that has the same resistance to borers and is well adapted to drought because of its deep-penetrating roots (Nassar et al., 2010).

\section{MATERIAL AND METHODS}

\section{Plant material}

The cassava cultivar UnB 032 and wild species $M$. fortalezensis were used to induce 
interspecific chimeras. UnB 032 is a low shrub of $1.5 \mathrm{~m}$ and yields $2-3 \mathrm{~kg} /$ year, and is diploid with $2 \mathrm{n}=36$, while $M$. fortalezensis is an erect woody shrub, ca. $4 \mathrm{~m}$ tall with deep fibrous roots, native to savanna forests of Ceará (Caatinga), Brazil, where drought predominates (Nassar et al., 2010), and is triploid with $2 \mathrm{n}=54$. Both are maintained at the living collection of the Universidade de Brasília (UnB).

Samples for determining layer genotype were collected from 9 clone plants replicated with stalks from the chimera plant (arising from the graft union region of UnB 032 and $M$. fortalezensis) and parental species, UnB 032 and M. fortalezensis. All clone plants were planted at the same time and under sunlight for comparative studies.

\section{Chimera development}

Stems of $M$. fortalezensis were whip grafted onto 40 rootstocks of UnB 032. Two months later, a cut parallel to the graft union was made leaving on a 5-mm scion. The graft unions and remaining graft tissue were covered by cotton, moistened with 4 drops $0.01 \% \alpha$-naphthaleneacetic acid, and repeated for 7 days (adapted from Kaddoura and Mantell, 1991) (Figure 1).

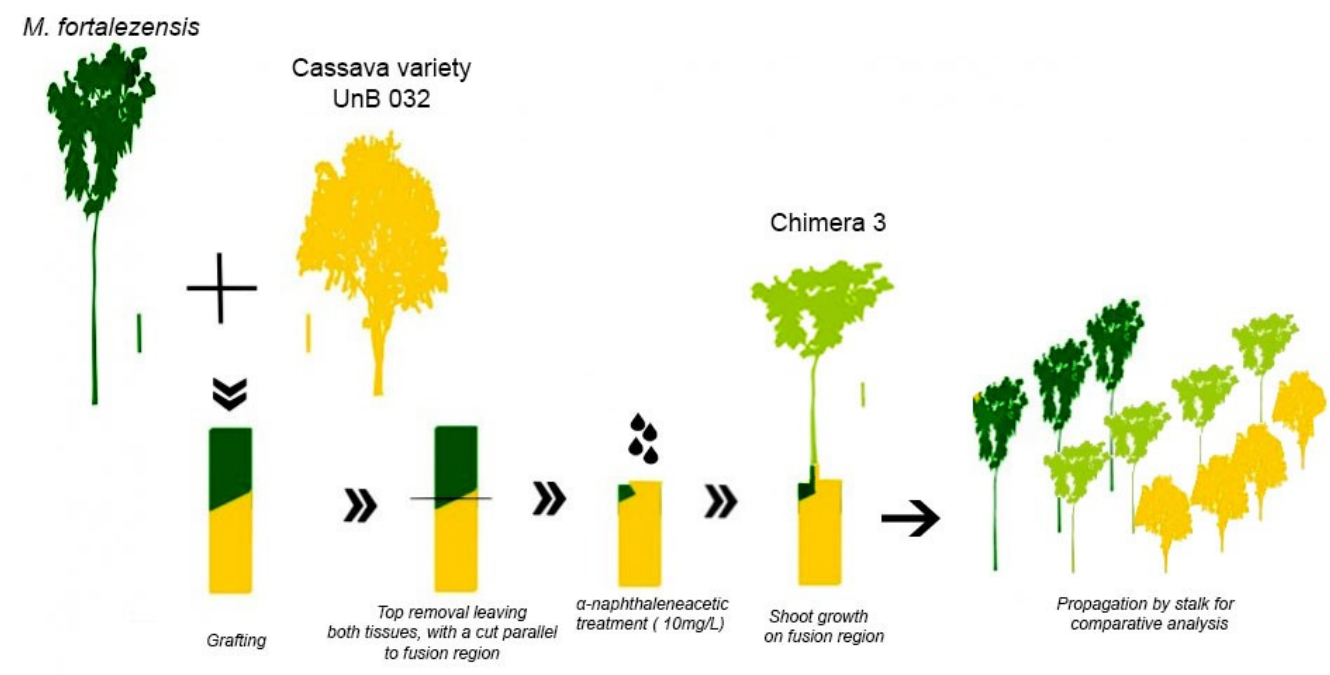

Figure 1. Chimera development by grafting.

At the end of the growing season, shoots that exhibited distinct morphological characters were propagated vegetatively for determination of tissue constitution. To characterize the layers, we analyzed the morphology of fruits, leaves and roots, meiosis in flower buds, mitosis in root cuttings, transversal petiole sections, longitudinal stem apex sections, and root production of chimera were compared with those of the parent species.

\section{Morphological characterization}

Nine mature clone plants of 12 months were examined for morphological character- 
ization based on distinctive characters of habit, leaves, inflorescence, fruits and roots, which distinguish cassava from other wild species (Rogers and Appan, 1973; Nassar et al., 1996).

\section{Cytogenetic analysis}

Male buds and closed mature staminate flowers of both parental plants and chimera were collected at 8:00 a.m. (daylight saving time), fixed in Carnoy solution, fixed in 70\% ethanol, smeared and stained with $1 \%$ acetocarmin. Root tips were collected from germinating chimera cuttings, pre-treated with $0.25 \%$ colchicine in distilled water for $2 \mathrm{~h}$, fixed in Carnoy solution, hydrolyzed in $5 \mathrm{~N} \mathrm{HCl}$ for $10 \mathrm{~min}$, smeared, and air-dried before being stained with 5\% Giemsa (adapted from de Carvalho and Guerra, 2002).

\section{Anatomical investigation}

Shoot apical meristems (SAMs), petioles and leaf blades were analyzed to help determine the layer genotype of the chimera considering meristem organization in 3 independent layers: L1 (outermost layer), L2 (next layer) and L3 (inner layer) (Marcotrigiano, 1997a). SAMs longitudinal sections, leaf blade surface and transversal sections of petioles and roots were analyzed. All materials were fixed using FAA solution (formaldehyde, 70\% ethanol and glacial acetic acid; 5:5:90, v/v) (Johansen, 1940) and permanently mounted in synthetic resin (Paiva et al., 2006). SAMs were embedded in butyl acetate series and paraffin (Kraus and Arduin, 1997), and 8- $\mu \mathrm{m}$ thick sections were obtained with a rotary microtome RM 2145 (LEICA, Germany) and doublestained with safranin and fast-green series (Kraus and Arduin, 1997). Leaf blade surface was released by glacial acetic acid and hydrogen peroxide solution and stained with $1 \%$ safranin (Kraus and Arduin, 1997). Petioles were free-hand cut on a microtome, and stained with $1 \%$ safranin and 1\% aqueous alcian blue (Kraus and Arduin, 1997). Roots were free-hand sectioned and treated with Lugol's solution (Johansen, 1940). Images highlighting trichomes were provided by a JEOL JSM 700 1-F scanning electron microscope, after gold coating in a Leica EM SCD 500 metalizer.

Epidermal features as leaf blade cell shape, trichomes, stomatal length, and petiole ordinary epidermal cell width helped determine L1 layer origin, once they are derived from it (Goffreda et al., 1990; Burge et al., 2002). Al least 4 clone plants were sampled. Stomatal length and trichome frequency were determined on the 4th and 6th leaves, based on nail polish imprints from the abaxial leaf surface; while petiole cell width was measured on fresh 6th leaf. Starch granule size and distribution on 3-cm diameter roots were observed to evaluate edible potential in 2 clone plants.

Photographs were taken under a light microscope (Leica DM2500, Germany). Shoot apices were photographed using interferential contrast.

\section{Root production evaluation}

Root weight was measured to estimate the potential production of Chimera 3. Two clone plants had all roots weighed 12 months after planting stalks.

\section{Statistical analyses}

Measurements were made using Image-Pro Plus version 4.5.0.29 and statistical analy- 
sis was performed with the Assistat 7.6 beta software. Variations on stomatal length, petiole epidermal and cortical cell width were evaluated by analysis of variance (ANOVA) followed by Tukey's test $(\mathrm{P}=0.05)$ to compare means.

\section{RESULTS}

\section{Morphological characterization}

Chimera 3 showed homogeneous characters on the whole plant, which were very distinctive characters when compared to parents (Table 1): semi-erect shrub ca. $4 \mathrm{~m}$ with semi-decumbent branches versus erect shrubs ca. $8 \mathrm{~m}$ in M. fortalezensis and ca. $2.5 \mathrm{~m}$ in UnB 032 (Figure 2 A-C); brevipeltate leaves with obovate lobes versus peltate obovate leaves in M. fortalezensis and emarginated oblong-lanceolate leaves in UnB 032, and tuberous cylindrical roots reaching $90 \mathrm{~cm}$ versus fibrous roots reaching $1.5 \mathrm{~m}$ in $M$. fortalezensis and tuberous conical roots of $30 \mathrm{~cm}$ in UnB 032 (Figure 2D-F).

Table 1. Morphological characterization of the Chimera 3 and parental species (Manihot fortalezensis and UnB 032).

\begin{tabular}{|c|c|c|c|}
\hline & M. fortalezensis (FFF) & Chimera 3(EFF) & Cassava UnB 032 (EEE) \\
\hline Plant habit and stems & $\begin{array}{l}\text { Erect shrub normally solitary, } \\
\text { ca. } 8 \mathrm{~m}, 7-10 \mathrm{~cm} \text { diameter, erect branch, } \\
\text { dichotomously branching only in the } \\
\text { apical part. Red young branch. } \\
\text { Slightly enlarged nodes, and not } \\
\text { enlarged stipels scars on stem. }\end{array}$ & $\begin{array}{l}\text { Semi-erect shrub ca. } 4 \mathrm{~m}, 1-2 \\
\text { central stems from the same } \\
\text { base, } 2-5 \mathrm{~cm} \text { diameter, } \\
\text { semi-decumbent branch, } \\
\text { dichotomously and } \\
\text { trichotomously branching. } \\
\text { Purple young branch. } \\
\text { Upper part of stems tetragonal. } \\
\text { Enlarged nodes and stipels scars. }\end{array}$ & $\begin{array}{l}\text { Erect shrub ca. } 2 \mathrm{~m}, 2-3 \text { central stems } \\
\text { arising from the same base, } 1-5 \mathrm{~cm} \\
\text { diameter, erect branch, dichotomously } \\
\text { and trichotomously branching. Green } \\
\text { reddish young branch. Enlarged and } \\
\text { small nodes and stipels scars. }\end{array}$ \\
\hline Leaf & $\begin{array}{l}\text { 3, } 5 \text { ou } 7 \text { lobes, normally peltate, } \\
\text { soft green adaxial face, and glauca } \\
\text { green abaxial face. Central lobes } \\
\text { broadly obovate with apiculate apex. } \\
\text { Petiole length } 10-25 \mathrm{~cm} \text {. }\end{array}$ & $\begin{array}{l}\text { Palmately leaf with } 1 \text { to } 7 \text { lobes, } \\
\text { normally } 5 \text { lobes, brevi-peltate, } \\
\text { deep green adaxial and } \\
\text { abaxial face. Central lobes } \\
\text { obovate with apiculate apex. } \\
\text { Petiole length } 10-40 \mathrm{~cm} \text {. }\end{array}$ & $\begin{array}{l}\text { 1-5 lobes, emarginate, deep green } \\
\text { adaxial and abaxial face. Central lobes } \\
\text { oblong-lanceolate with } \\
\text { acuminate acute apex. Petiole length } \\
\text { 7-30 cm. }\end{array}$ \\
\hline Inflorescence & $\begin{array}{l}\text { Panicle with } 2 \text { lateral branches from } \\
\text { the same base, with pistilate flowers } \\
\text { in the central panicle. Flowers length } \\
15 \mathrm{~mm} \text {. Ovaries no winged. }\end{array}$ & $\begin{array}{l}\text { Inflorescence in panicle with 2-3 } \\
\text { lateral branches from the same } \\
\text { base. Flowers length } 14 \mathrm{~mm} \text {. } \\
\text { Ovaries winged. }\end{array}$ & $\begin{array}{l}\text { Inflorescence in panicle with } 2-3 \text { lateral } \\
\text { branches arising from the same base. } \\
\text { Flowers length } 9 \mathrm{~mm} \text {. Ovaries with red } \\
\text { wings. }\end{array}$ \\
\hline Fruit & $\begin{array}{l}\text { Globose fruits not winged, except on } \\
\text { base, being slender straight wings, } \\
\text { with peduncle forming a globe } \\
\text { near to the fruit. }\end{array}$ & $\begin{array}{l}\text { Globose fruits with slender } \\
\text { straight wings in whole fruit, } \\
\text { with peduncle forming a globe } \\
\text { near to the fruit. }\end{array}$ & $\begin{array}{l}\text { Semi-esferic fruits with ondulate wings } \\
\text { in whole fruit, with a thickened } \\
\text { peduncle. }\end{array}$ \\
\hline Root $^{1}$ & $\begin{array}{l}1.5 \mathrm{~m} \text {. Predominantly narrow fibrous } \\
\text { roots and rare } 2.5 \mathrm{~cm} \text { diameters roots. }\end{array}$ & $\begin{array}{l}\text { Tuberous cylindrical roots } \\
\text { reaching } 90 \mathrm{~cm} \text {. Predominantly } \\
\text { tuberous roots with } 5 \mathrm{~cm} \text { diameter. } \\
\text { Light cream periderm. }\end{array}$ & $\begin{array}{l}\text { Tuberous conical roots reaching } 30 \mathrm{~cm} \text {. } \\
\text { Predominantly tuberous root with } 7 \mathrm{~cm} \\
\text { diameter (base). Light cream periderm. }\end{array}$ \\
\hline
\end{tabular}

${ }^{1}$ Twelve-month-old plants. The three letters (FFF, EFF or EEE) represent L1, L2 and L3 layers, respectively. F = M. fortalezensis; E = Manihot esculenta.

\section{Cytogenetic characterization}

Meiotic metaphase I and mitotic metaphase analyses showed 2n $=54$ in Chimera 3 (Figure 3), demonstrating the same chromosome number as $M$. fortalezensis in inner tissues of the chimera. 

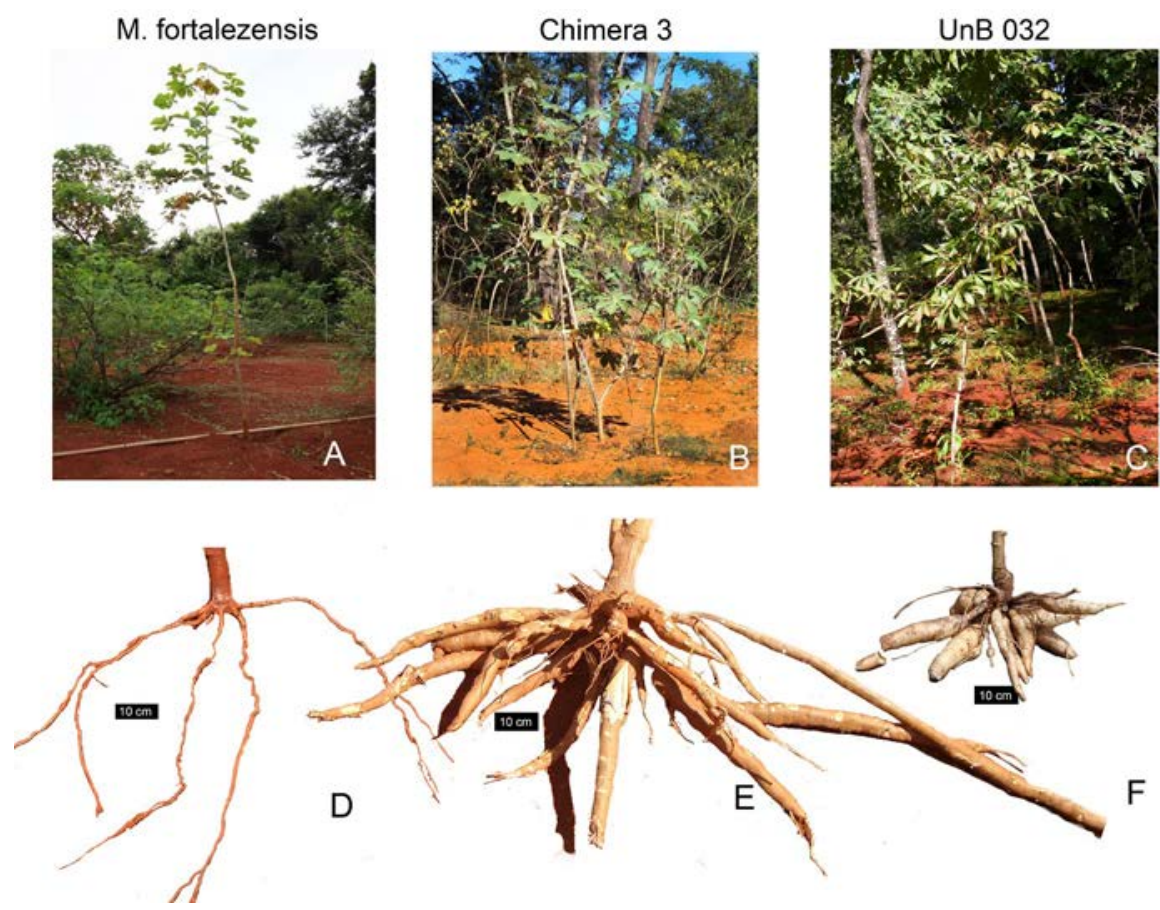

Figure 2. Whole plant and roots of Chimera 3 (centre) compared to parental species Manihot fortalezensis (left) and Manihot esculenta (cassava variety UnB 032) (right): A. erect shrub normally solitary ca. $8 \mathrm{~m}$. B. Chimera 3: semi-erect shrub ca. 4 m, with branches. C. Cassava variety UnB 032: erect shrub with branches ca. 2 m.
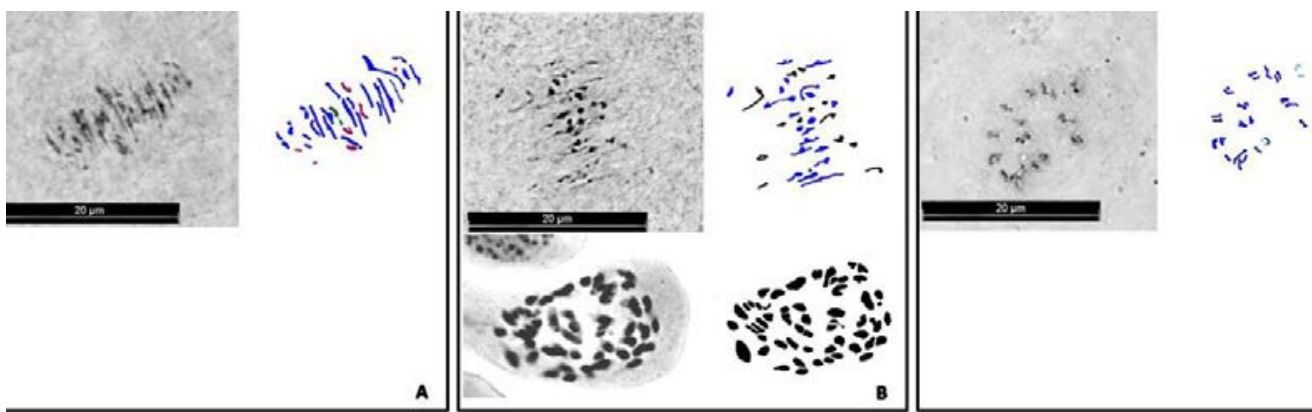

Figure 3. Meiotic metaphase I (upper part) of Chimera 3 and parental species, and mitotic metaphase of Chimera 3. A. Manihot fortalezensis; B. Chimera 3; C. UnB 032. Colored marks represent bivalents and univalents on meiotic metaphase I (blue = bivalents; black = univalents). On mitotic metaphase all black marks represent a chromosome. Bar $=20 \mu \mathrm{m}$.

\section{Anatomical investigation}

\section{Stem apical meristem, leaf blade and petiole}

In the stem apical meristem, the three species showed no size difference between their 
own three outermost meristem cell layers, but it was possible to note a larger cell size in Chimera 3 and $M$. fortalezensis when compared to UnB 032 cells (Figure 4A-C).

Leaf epidermis of Chimera 3 resembled that of cassava variety UnB 032 and differed from that of M. fortalezensis: it showed regular ordinary cell shape (Figure 4D-F) and tector trichomes over adaxial leaf veins, which are cassava-specific features (Figure 4G-I). Stomatal length and petiole epidermal cell width were intermediate when compared to parents (Table 2 and Figure 4D-F, J-L). Furthermore, Chimera 3 could be distinguished by cell content of inner petiole tissue, showing fewer starch granules but more calcium oxalate druses than in parents, in general (Table 2).
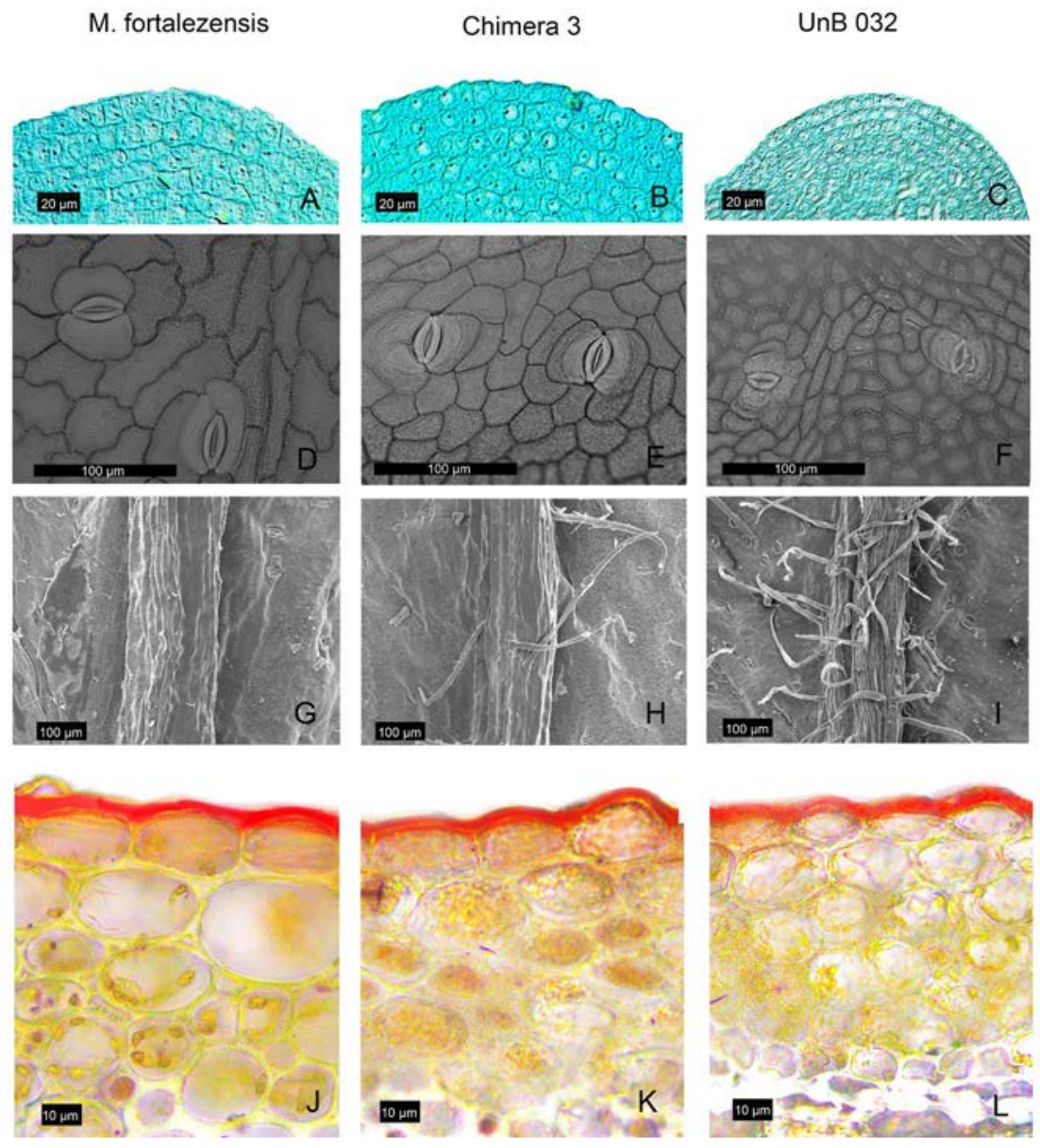

Figure 4. Anatomical characterization of Chimera 3 compared to parents: Manihot fortalezensis and cassava cultivar UnB 032. A. B. C. Cell layers on stem apical meristem. No different cell size between layers. D. E. F. Ordinary cell shape and stomatal length. Regular ordinary cell shape in Chimera 3, as in cassava variety UnB 032. Stomatal intermediary lenght in Chimera 3. G. H. I. Trichome on leaf adaxial face veins. Trichome presence on Chimera 3, distinghish it from $M$. fortalezensis. J. K. L. Petiole epidermal and cortical cells. Intermediary width Chimera 3 epidermal cells and similar to UnB 032 cortical cells. Thick cuticle (red stained) on all plants. 
Table 2. Leaf characterization showing distinct anatomical characters of Chimera 3 compared to parental species: Manihot fortalezensis and cassava cultivar UnB 032, on the $6^{\text {th }}$ node.

\begin{tabular}{|c|c|c|c|}
\hline & M. fortalezensis (FFF) & Chimera 3 (EFF) & Cassava UnB 032 (EEE) \\
\hline $\begin{array}{l}\text { Leaf epidermal cells size } \\
\text { and shape (adaxial view) }\end{array}$ & $\begin{array}{l}\text { Larger cells with sinuous } \\
\text { anticlinal walls }\end{array}$ & $\begin{array}{l}\text { Medium cells with regular } \\
\text { anticlinal walls }\end{array}$ & $\begin{array}{l}\text { Small cells with regular } \\
\text { anticlinal walls }\end{array}$ \\
\hline $\begin{array}{l}\text { Stomatal length } \\
\text { (abaxial view) }\end{array}$ & $18.10 \pm 1.643^{\mathrm{a}} \mu \mathrm{m}$ & $17.54 \pm 2.167^{\mathrm{ab}} \mu \mathrm{m}$ & $14.73 \pm 1.103^{\mathrm{b}} \mu \mathrm{m}$ \\
\hline $\begin{array}{l}\text { Trichomes over the leaf } \\
\text { blade veins (adaxial view) }\end{array}$ & Absent & Low frequency & High frequency \\
\hline Petiole epidermis & \multicolumn{3}{|c|}{$\begin{array}{l}\text { All species show non-stratified epiderm with thickened cell walls and cuticle. The species differ only in } \\
\text { shape and width }\end{array}$} \\
\hline Cell shape & $\begin{array}{l}\text { Tabular to oval cells frequently } \\
\text { intercalated by isodiametric cells }\end{array}$ & Oval to isodiametric cells & Isodiametric cells \\
\hline Cell width* & $24 \pm 4.636^{\mathrm{a}} \mu \mathrm{m}$ & $19.57 \pm 2.5298^{\mathrm{ab}} \mu \mathrm{m}$ & $14.96 \pm 1.4212^{\mathrm{b}} \mu \mathrm{m}$ \\
\hline Petiole cortex & \multicolumn{3}{|c|}{$\begin{array}{l}\text { The three species has a parenchymatous tissue intercalated by lamelar collenchyma tissue, showing the same } \\
\text { number of cell layers in the three (4-7 at outermost parenchyma, 3-5 at collenchyma and inner parenchyma). } \\
\text { The difference between the species is noted in the cell size, shape of the outermost parenchyma, and content of } \\
\text { the inner parenchyma. The three species has calcium oxalate druses at the inner parenchyma, but } \\
\text { M. fortalezensis show a lower frequency of this salt }\end{array}$} \\
\hline \multicolumn{4}{|l|}{ Outermost parenchyma } \\
\hline Cell shape & Oval cell & Oval cell & Isodiametric cell \\
\hline Cell width* & $29.70 \pm 1.23^{\mathrm{a}} \mu \mathrm{m}$ & $21.93 \pm 0.46^{\mathrm{b}} \mu \mathrm{m}$ & $18.60 \pm 0.39^{\mathrm{b}} \mu \mathrm{m}$ \\
\hline \multicolumn{4}{|l|}{ Collenchyma } \\
\hline Cell width* & $20.37 \pm 4.647^{\mathrm{a}} \mu \mathrm{m}$ & $13.79 \pm 1.697^{\mathrm{b}} \mu \mathrm{m}$ & $13.16 \pm 1.7291^{\mathrm{b}} \mu \mathrm{m}$ \\
\hline \multicolumn{4}{|l|}{ Inner parenchyma } \\
\hline Cell width* & $32.98 \pm 2.98^{\mathrm{a}} \mu \mathrm{m}$ & $30.42 \pm 3.568^{\mathrm{a}} \mu \mathrm{m}$ & $28.95 \pm 0.9115^{\mathrm{a}} \mu \mathrm{m}$ \\
\hline Cell content & $\begin{array}{l}\text { Low frequency of calcium } \\
\text { oxalate druses }\end{array}$ & $\begin{array}{l}\text { Frequent calcium oxalate } \\
\text { druses }\end{array}$ & Frequent calcium oxalate druses \\
\hline Endodermis & There is a different starch grains an & calcium oxalate druses frequency & etween the species. \\
\hline Cell content & $\begin{array}{l}\text { Starch grains and calcium oxalate } \\
\text { druses very frequent }\end{array}$ & $\begin{array}{l}\text { Starch grains infrequent and } \\
\text { calcium oxalate druses frequent }\end{array}$ & $\begin{array}{l}\text { Starch grains and calcium oxalate } \\
\text { druses infrequent }\end{array}$ \\
\hline Pericyclic fibers & \multicolumn{3}{|l|}{ Poligonal fibers often gelatinous } \\
\hline Petiole vascular bundles & \multicolumn{3}{|c|}{$\begin{array}{l}\text { Bicolateral bundles in ring, having a phloem with some laticifers, easily to notice in } M \text {. fortalezensis } \\
\text { There were differences in the content of parenchyma phloem cells }\end{array}$} \\
\hline Cell content & Lacking druses & Lacking druses & Druses seldom noted \\
\hline Vascular bundle (\#) & 8 & 9 to 11 & 9 and 10 \\
\hline Xylem & \multicolumn{3}{|c|}{ Xylem composed by vessel of the same diameter, but of varied number of rays } \\
\hline Xylem vessel rays & 7 to 10 & 6 to 8 & 5 to 8 \\
\hline Petiole medulla & \multicolumn{3}{|c|}{$\begin{array}{l}\text { Polyhedral cells containing starch grains and calcium oxalate druses near of the bundles } \\
\text { Differing only in cell content. }\end{array}$} \\
\hline Cell content & $\begin{array}{l}\text { Starch grains frequent } \\
\text { Druses seldom found }\end{array}$ & $\begin{array}{l}\text { Starch grains seldom noted } \\
\text { Druses often noted }\end{array}$ & $\begin{array}{l}\text { Starch grains seldom noted } \\
\text { Lack druses }\end{array}$ \\
\hline
\end{tabular}

*Mean and standard deviation. Different letters in the same line indicate significant differences among means according to the Tukey range test $(\mathrm{P} \leq 0.05)$. Stomatal length: $\mathrm{N}=5$; petiole cell width: $\mathrm{N}=4$. \# $=$ number of vascular bundles on petiole transversal section.

\section{Root production and starch granules size and distribution}

Chimera 3 production was $14 \mathrm{~kg}$ per plant, in a 12 month-old plant, while cassava variety UnB 032 with the same age produced $2.1 \mathrm{~kg}$ per plant, denoting vigorous plant growth. Chimera 3 reached $4 \mathrm{~m}$ high, while cassava variety UnB 032 was $2 \mathrm{~m}$ tall under the same conditions.

Anatomic analysis indicated the Chimera 3 starch granules were similar as in cassava with round shape but differed in diameter (Table 3) compared to cassava UnB 032. Starch granules were present in whole xylem, except vessel elements, axial parenchyma and fibers of primary xylem, while in cassava there were granules in axial parenchyma and a lesser portion of primary xylem without starch granules. Phloem also displayed parenchyma and fiber cells completely filled with starch granules, except sieve tubes, companion cells and laticifers. Chimera 3 starch granules were small, while cassava granules were medium sized, following Lindeboom et al. (2004) size classification. 
Table 3. Starch granules diameters (means \pm standard deviation, minimum and maximum) of Chimera 3 and cassava cultivar UnB 032 on xylem parenchyma cells.

\begin{tabular}{lccc}
\hline & \multicolumn{3}{c}{ Diameter $(\mu \mathrm{m})$} \\
\cline { 2 - 4 } & Means \pm standard deviation & Mininum & Maximum \\
\hline Quimera 3 & $6.4 \pm 2.6$ & 2.8 & 11.9 \\
UnB 032 & $15.3 \pm 4.4$ & 7.6 & 23.4 \\
\hline
\end{tabular}

\section{DISCUSSION}

\section{Chimera production potential}

Chimera 3 showed a set of features distinct from that of the two parental species (Table 1), which can be considered new features, because they are not exhibited by the parents: height, branching, leaf, fruit and root shape. It showed to be more vigorous than both parental species, once it produced very large and quite edible roots, which were almost 7-fold larger than cassava (UnB 032), while the wild species $M$. fortalezensis did not yield tuberous roots. Chimera 3 root phenotype was long, tuberous and weighted $14 \mathrm{~kg}$ per plant, while cassava parent roots, although tuberous, were short and yielded only $2.1 \mathrm{~kg}$ per plant with the same age. Apparently, an interaction of the genotypes resulted in a novel feature. We hypothesize that this new phenotype ensues from an epigenetic interaction between the two interspecies coexisting in the chimera. Recently, epigenetic alterations causing heritable complex traits such as plant height have been reported (Johannes et al., 2009). Epigenetic alterations, on specific locus, were also noted in plants, where two species coexisted on the same individual, being attributed to the interaction between species (Wu et al. 2013). This phenomenon was cited as a possible molecular basis for phenotype changes as noted in grafts, called graft hybridization, and heterosis (Tsaftaris et al., 2008; Johannes et al., 2009; Wu et al., 2013).

Chimeric roots proved to be edible according to transversal sections showing parenchyma cells filled with round starch granules. Starch granule distribution of this chimera denotes an edible root very similar to that of cassava. They also showed small granules, which allows faster starch hydrolysis, suitable for the manufacture of fine printing paper and biodegradable films (Lindeboom et al., 2004).

\section{Chimeric tissue identification}

\section{Stem apical meristem}

Considering that a chimeric plant is a mosaic with genetically different cells existing in the SAM (Marcotrigiano, 1997a), Chimera 3 apical meristem, when anatomically analyzed, did not showed size difference between layers. That is coherent when ploidy level difference is evaluated (only one set of chromosomes, i.e., 1n). All layers showed the same size, which were similar to $M$. fortalezensis. This is expected, once cell size control of L1 (the outermost layer) is not autonomous, meaning that it depends on adjacent cell layer size (Savaldi-Goldstein et al., 2007; Marcotrigiano, 2010). 


\section{L1 tissue constitution by morphological and anatomical epidermal cell assessment}

The presence of wing on the fruits allows to determine L1 constitution (Tabela 1), because this "diagnostic trait" belongs to cassava (Rogers and Appan 1973; Nassar et al., 1996). Additionally, epidermal traits, such as ordinary cell shape and width, trichomes, and stomatal length and petiole cell width, were used to determine L1 constitution, once they are derived from it (Table 2 and Figure 4) (Satina et al., 1940; Goffreda et al., 1990; Evert, 2007; Marcotrigiano, 2010).

Ordinary epidermal cell shape was identical to cassava variety shape and different from that of $M$. fortalezensis (Figure 4), indicating the cassava variety UnB 032 on the epidermis.

Trichomes were found only on Cassava variety UnB 032 and Chimera 3 (Figure 4GI), denoting a cassava presence on the epidermis. However, trichomes were present in a lower frequency on Chimera 3, which probably demonstrate an interaction between cassava pubescent epidermis and $M$. fortalezensis glabrous tissues (inner tissues).

Stomatal length and petiole epidermal cell width demonstrated intermediary cell size to parental species $M$. fortalezensis and $M$. esculenta (cassava variety UnB 032), which is in accordance to the stem apical meristematic cells, since it was not noted cell size difference between layers (Figure 4A-C) and epidermal cell size is controlled by internal tissue development (Savaldi-Goldstein et al., 2007; Marcotrigiano, 2010).

\section{L2 and L3 layer constitution by cytogenetic analysis}

Meiotic chromosome counts allowed L2 layer characterization, because gametes usually derive from the L2 layer (Satina et al., 1940; Goffreda et al., 1990). The meiotic metaphase 1 in pollen mother cells showed 54 chromosomes on the Chimera 3 as in $M$. fortalezensis (Figure 3), while in cassava (UnB 032), it was $2 n=36$. Therefore, is deduced that $L 2$ layers were constituted by $M$. fortalezensis.

Chromosome counts on adventitious root tips allowed determine the innermost layer constitution, because this roots originate in pericycle, which is derived from L3 layer (Evert, 2007; Medina et al., 2007; Bomfim et al., 2011). On this counting, 54 chromosomes were noted, which confirms the same ploidy of parental species $M$. fortalezensis.

Those analyses demonstrated the Chimera 3 constitutuion as EFF, which represents L1, L2 and L3 layers, respectivally, being "E" to M. esculenta UnB 032, and "F" to M. fortalezensis. Judging by the uniformity of characters on whole plant, it was deduced that Chimera 3 has a periclinal arrangement, where whole epidermis is constituted by $M$. esculenta (cassava variety UnB 032).

\section{CONCLUSIONS}

Chimera development offers an important tool for crop improvement with a great potential to boost production, especially in cassava, which has the advantage of vegetative propagation.

This method is useful, specially, to combine species that by conventional methods, as hybribization, are hardly to combine triploid species. The chimera seemed to be a valuable material to study the mecanism under the great increase of roots, furthermore to be quite 
useful to cassava yield. We demonstrate a new approach to plant breeding based on chimera interespecific synthesis having two species tissues.

\section{ACKNOWLEDGMENTS}

We are grateful to Conselho Nacional de Desenvolvimento Científico e Tecnológico (CNPq, Brasília) for providing funding for this research; to the Canadian International Development Research Center (IDRC) for helping to establish the living collection at Universidade de Brasília, and to Coordenação de Aperfeiçoamento de Pessoal de Nível Superior (CAPES) for supporting PhD student (N.N. Bomfim).

\section{REFERENCES}

Aversano R, Caruso I, Aronne G, De Micco V, et al. (2013). Stochastic changes affect Solanum wild species following autopolyploidization. J. Exp. Bot. 64: 625-635.

Bomfim NN, Graciano-Ribeiro D and Nassar NM (2011). Genetic diversity of root anatomy in wild and cultivated Manihot species. Genet. Mol. Res. 10: 544-551.

Burge GK, Morgan ER and Seelye JF (2002). Opportunities for synthetic plant chimeral breeding: past and future. Plant Cell Tissue Organ Cult. 70: 13-21.

Ceballos H, Iglesias CA, Perez JC and Dixon AG (2004). Cassava breeding: opportunities and challenges. Plant Mol. Biol. 56: 503-516.

Chen LP, Ge YM and Zhu XY (2006). Artificial synthesis of interspecific chimeras between tuber mustard (Brassica juncea) and cabbage (Brassica oleracea) and cytological analysis. Plant Cell Rep. 25: 907-913.

de Carvalho R and Guerra M (2002). Cytogenetics of Manihot esculenta Crantz (cassava) and eight related species. Hereditas 136: 159-168.

Evert RF (2007). Esau's Plant Anatomy: Meristems, Cells, and Tissues of the Plant Body: Their Structure, Function, and Development. John Wiley \& Sons, New Jersey.

FAO (2013). Save and Grow: Cassava - A Guide to Sustainable Production Intensification. Food and Agriculture Organization of the United Nations, Rome.

Goffreda JC, Szymkowiak EJ, Sussex IM and Mutschler MA (1990). Chimeric tomato plants show that aphid resistance and triacylglucose production are epidermal autonomous characters. Plant Cell 2: 643-649.

Johannes F, Porcher E, Teixeira FK, Saliba-Colombani V, et al. (2009). Assessing the impact of transgenerational epigenetic variation on complex traits. PLoS Genet. 5: e1000530.

Johansen DA (1940). Plant Microtechnique. (Sinott EW, ed.). Available at [http://books.google.com.br/ books?id=dNvQAAAAMAAJ].

Kaddoura RL and Mantell SH (1991). Synthesis and characterization of Nicotiana-Solanum graft chimeras. Ann. Bot. 68: 547-556.

Kraus JE and Arduin M (1997). Manual Básico de Métodos em Morfologia Vegetal. EDUR, Seropédica.

Lindeboom N, Chang PR and Tyler RT (2004). Analytical, biochemical and physicochemical aspects of starch granule size, with emphasis on small granule starches: a review. Starch - Stärke 56: 89-99.

Lindsay GC, Hopping ME, Binding H and Burge GK (1995). Graft chimeras and somatic hybrids for new cultivars. New Zealand J. Bot. 33: 79-92.

Marcotrigiano M (1997a). Genetic Mosaics and Plant Improvement. In: Plant Breeding Reviews (Jules J, ed.). John Wiley \& Sons, Inc., Oxford, 43-84.

Marcotrigiano M (1997b). Chimeras and variegation: patterns of deceit. HortScience 32: 773-784.

Marcotrigiano M (2010). A role for leaf epidermis in the control of leaf size and the rate and extent of mesophyll cell division. Am. J. Bot. 97: 224-233.

Marcotrigiano M and Gouin FR (1984). Experimentally synthesized plant chimeras 2. a comparison of in vitro and in vivo techniques for the production of interspecific nicotiana chimeras. Ann. Bot. 54: 513-521.

Medina RD, Faloci MM, Gonzalez AM and Mroginski LA (2007). In vitro cultured primary roots derived from stem segments of cassava (Manihot esculenta) can behave like storage organs. Ann. Bot. 99: 409-423.

Nassar NMA and Ortiz R (2009). Cassava Genetic Resources: Manipulation for Crop Improvement. In: Plant Breeding Reviews (Jules J, ed.). John Wiley \& Sons. Inc., Hoboken, 247-275. 
Nassar N and Ortiz R (2010). Breeding cassava to feed the poor. Sci. Am. 302: 78-82, 84.

Nassar N and Bomfim N (2012). Induction of Productive periclinal chimera in cassava. Gene Conserve 11:3-6.

Nassar NM and Bomfim N (2013). Synthesis of periclinal chimera in cassava. Genet. Mol. Res. 12: 610-617.

Nassar NMA, Carvalho CG and Vieira C (1996). Overcoming crossing barriers between cassava, Manihot esculenta crantz and a wild relative, M. pohlii Warwa. Braz. J. Genet. 19: 617-620.

Nassar NMA, Graciano-Ribeiro D, Bomfim NN and Gomes PTC (2010). Manihot fortalezensis Nassar, Ribeiro, Bomfim et Gomes a New Species of Manihot from Ceará, Brazil. Genet. Resour. Crop Evol. 58: 831-835.

Paiva JGA, Fank-de-Carvalho SM, Magalhães MP and Graciano-Ribeiro D (2006). Verniz Vitral Incolor 500: uma alternativa de meio de montagem economicamente viável. Acta Bot. Brasilica 20: 257-264.

Rieseberg LH and Carney SE (1998). Plant Hybridization. New Phitologist 140: 599-524.

Rogers DJ and Appan SG (1973). Manihot, Manihotoides (Euphorbiaceae). Flora, New York.

Satina S, Blakeslee AF and Avery AG (1940). Demonstration of the three germ layers in the shoot apex of datura by means of induced polyploidy in periclinal chimeras. Am. J. Bot. 27: 895-905.

Savaldi-Goldstein S, Peto C and Chory J (2007). The epidermis both drives and restricts plant shoot growth. Nature 446: 199-202.

Sreekumari MT, Jos JS and Nair SG (1999). ‘Sree harsha’: a superior triploid hybrid in cassava”. Euphytica 106: 1-6.

Stewart RN, Meyer FG and Dermen H (1972). Camellia + "Daisy Eagleson” a graft chimera of Camellia sasanqua and C. japonica. Am. J. Bot. 59: 515-524.

Tsaftaris AS, Polidoros AN, Kapazoglou A, Tani E, et al (2008). Plant Breeding Reviews (Janick J, ed.). Wiley, New York.

Ulukan H (2009). The evolution of cultivated plant species: classical plant breeding versus genetic engineering. Plant Systematics Evol. 280: 133-142.

Wu R, Wang X, Lin Y, Ma Y, et al. (2013). Inter-species grafting caused extensive and heritable alterations of DNA methylation in Solanaceae plants. PLoS One 8: e61995.

Zhang M, Deng XX, Qin CP, Chen C, et al. (2007). Characterization of a new natural periclinal navel - satsuma chimera of citrus: 'zaohong' navel orange. J. Am. Soc. Horticult. Sci. 132: 374-380.

Zhou J, Hirata Y, Nou I, Shiotani H, et al. (2002). Interactions between different genotypic tissues in citrus graft chimeras. Euphytica 126: 355-364. 